Priorities in Developing Countries. 2nd edition. Washington (DC): The International Bank for Reconstruction and Development / The World Bank. Chapter 25

2. Nair $\mathbf{H}$ et al (2010). Global burden of acute lower respiratory infections due to respiratory syncytial virus in young chil-dren: a systematic review and meta analysis. Lancet, 375, pp.1545 - 1555.

3. Quyết định số 101/QĐ-BYT ngày 09 tháng 01 năm 2014 Bộ Y Tế. Hướng dẫn xử trí viêm phổi cộng đồng ở tré em.

4. Tran DN, Pham TMH, Ha MT et al (2013). Molecular epidemiology and disease severity of human respiratory syncytial virus in Vietnam. PLoS One, 8(1), e45436.

5. Nokes DJ et al (2009). Incidence and Severity of Respiratory Syncytial Virus Pneumonia in Rural Kenyan Children Identified through Hospital Surveillance. Clinical Infectious Diseases, 49, 1341 - 1349.

6. Lê Thi Hồng Hanh. Đắc điểm dich tê̂ hoc lầm sàng ở trẻ viêm phổi nặng có nhiếm RSV tại Trung tâm Hô hấp Bệnh viện Nhi Trung ương. Tạp chí nghiên cứu và thực hành Nhi khoa. 2020; 4 (5): 1-9.

7. Guo $W$, Wang J, Sheng $M$ et al (2012). Radiological findings in 210 paediatric patients with viral pneumonia: a retrospective case study. $\mathrm{Br}$ J Radiol; 85(1018):1385-1389.

\title{
ĐÁNH GIÁ HIỂU BIẾT VÀ SỰ HÀI LÒNG CỦA NGƯờI BỆNH VỀ VIỆC CUNG CẤP THÔNG TIN CẦN THIẾT TRƯớC MỔ ở NGƯờI BỆNH PHẪU THUẬT TÁI TẠO DÂY CHẰNG CHÉO TRƯớC TẠI BỆNH VIỆN ĐẠI HỌC Y HÀ NộI
}

\section{TÓM TẮT}

Mục tiêu: Đánh giá hiểu biết và sự hài lòng của người bệnh về những thông tin cần thiết trước mổ ở người bểnh mổ nội soi tái tạo dây chằng chéo trước khớp gối tại Bệnh viện Đai học Y Hà Nội. Đối tượng và phương pháp nghiên cứu: Phỏng vấn ngâuu nhiên 86 người bênh mổ nôi soi tái tao dây chẳng chéo trước khớp gối tại Bệnh viện Đại học Y Hà Nội trong thời gian từ tháng 6 năm 2019 đến hết tháng 12 năm 2020 theo một bộ câu hỏi được thiết kế để đánh giá hiểu biết và sự hà̉i lòng của người bênh về viêc cung cấp những thông tin cần thiết trước mổ tại thời điểm trước khi đi mổ. Kết quả nghiên cứu: Thây thuốc có xu hướng cung cấp nhiều thông tin về chẩn đoán bênh, tổn thương giải phấu của khớp gối, lý do phải mổ, can thiệp của bác sĩ trong mổ, các biến chứng chính sau mổ, khả năng thành công của ca mổ so với các thông tin về cảm giác của người bênh sau mổ, đau và kiểm soát đau sau mổ, thời gian cần nghỉ việc sau mổ và các lưu ý trong sinh hoạt sau mổ. Người bệnh chưa hài lòng với việc cung cấp các thông tin cân thiết trước mổ tái tạo dây chẳng chéo trước. Kết luận: Quá trình cung cấp thông tin cần thiết trước mổ của thầy thuốc cho người bểnh tái tao dây chằng chéo trước cân được thực hiện hiệu quả hơn để người bênh thực sự chia sẻ quyết đđịnh điêu trị và hài lòng với quá trình cung cấp thông tin đó.

Tư khóa: đồng thuân dưa trên sự hiểu biết; nôi soi khớp gối; tái tạo dây chằng chéo trước; Đại học Y Hà Nội

${ }^{1}$ Trường Đại học Y Hà Nôi

${ }^{2}$ Bênh viên Đai hoc Y Hà Nôi.

Chịu trách nhiệm chính: Đỗ Văn Minh

Email: mindovan@hmu.edu.vn

Ngày nhận bài: 11.6.2021

Ngày phản biên khoa hoc: 30.7.2021

Ngày duyệt bài: 12.8 .2021
Đỗ Văn Minh ${ }^{1,2}$
SUMMARY

EVALUATION OF PATIENT

COMPREHENSION AND SATISFACTION IN

INFORMED CONSENT FOR ARTHROSCOPIC ANTERIOR CRUCIATE LIGAMENT

RECONSTRUCTION IN HANOI MEDICAL UNIVERSITY HOSPITAL

Objectives: To evaluate the patient comprehension and satisfaction in informed consent for arthroscopic anterior cruciate ligament reconstruction in Hanoi Medical University Hospital. Materials and method: A total 86 patients undergoing arthroscopic anterior cruciate ligament reconstruction were randomized to ask to complete a detailed questionnairethat designed to evaluate the patient comprehension and satisfaction of the informed consent process prior to the operating room in Hanoi Medical University Hospital from June 2019 to December 2020. Results: Doctors provided more information aboutmain diagnosis, anatomical injuries in the knee joint, reason for surgery, doctor's interventions, major complications than information about post- operative feeling, pain and paincontrol, time off work, chances of successful surgery and precautions in daily activities. Almost patients felt normal with informed consent process. Conclusion: The informed consent process for arthroscopic anterior cruciate ligament reconstruction should be done more effectively to make patientan informed decision to surgery and satisfy with its process.

Keyword: informed consent; knee arthroscopy, anterior cruciate ligament reconstruction, Hanoi Medical University Hospital.

\section{I. ĐẶT VẤN ĐỀ}

Đồng thuận dựa trên sự hiểu biết sau khi đã được cung cấp các thông tin cần thiết là một vấn 
đề hết sức quan trọng trong thực hành lâm sàng nói chung và thực hành lâm sàng ngoại khoa nói riêng. Trước khi tiến hành các thủ thuật, phẫu thuật cho người bệnh, người thầy thuốc cần phải cung cấp đầy đủ các thông tin cần thiết cho người bệnh về những thủ thuật, phẫu thuật đó bằng các ngôn từ dễ hiểu để người bệnh có thể tiếp cận vấn đề. Trên cơ sở hiểu biết sau khi đã được giải thích, sự chia sẻ quyết định giữa người bệnh và thầy thuốc là một vấn đề cớ bản của chăm sóc y tế lấy người bệnh làm trung tâm [1]. Hiểu biết về những thông tin cần thiết đối với dịch vụ chăm sóc y tế, đặc biệt là các thủ thuật, phẫu thuật chấn thương chỉnh hình không chỉ giúp cho người bệnh và người nhà phối hợp tốt với nhân viên y tế trong quá trình điều trị mà còn chủ động trong kế hoạch điều trị của mình. Tuy nhiên, trong thực hành lâm sàng, nhiều khi việc cung cấp thông tin cần thiết cho người bệnh trước thủ thuật, phẫu thuật và ký giấy đồng ý thực hiện thủ thuật, phẫu thuật mang ý nghĩa hành chính nhiều hơn là sự chia sẻ quyết định giữa người bệnh và thây thuốc [2]. Bởi thế chúng tôi tiến hành nghiên cứu đề tài nhằm đánh giá hiểu biết và sự hài lòng của người bệnh sau khi được cung cấp những thông tin cần thiết trước mổ ở người cần phẫu thuật nội soi tái tạo dây chằng chéo trước nhằm mục tiêu: Đánh giá hiểu biết và sự hài lòng của người bệnh về những thông tin cần thiêt trước mổ ở người bệnh mổ nội soi tái tạo dây chằng chéo trước khớp gối tại Bềnh viện Đại hoc Y Hà Nội.

\section{II. ĐỐI TƯỢNG VÀ PHƯƠNG PHÁP NGHIÊN CỨU}

2.1 Đối tượng nghiên cứu. Gồm 86 người bệnh đứt dây chằng chéo trước khớp gối được điều trị phẫu thuật tại Khoa Chấn thương chỉnh hình và $y$ học thể thao Bệnh viện Đại học $Y$ Hà Nội trong thời gian từ tháng 6 năm 2019 đến hết tháng 12 năm 2020 được lựa chọn một cách ngẫu nhiên.

2.2 Thiết kế nghiên cứu. Nghiên cứu mô tả cắt ngang thu thập thông tin định tính thông qua phỏng vấn sâu.

2.3 Quy trình nghiên cứu. Tất cả người bệnh đên khám và điều trị phấu thuật nội soi tái tạo dây chằng chéo trước khớp gổi đều được cung cấp thông tin cần thiết trước phẫu thuật tại thời điểm khám bênh để làm hồ sơ phẫu thuẩt bởi bác sĩ khám bệnh đồng thời là phẫu thuật viên thực hiện ca mổ và bởi bác sĩ nội trú năm cuối chuyên ngành ngoại khoa đi học lâm sàng tại đơn vị ngay trước ngày phẫu thuật. Tất cả người bệnh đều được phỏng vấn trực tiếp để hoàn thành bộ câu hỏi đánh giá sự hiểu biết và hài lòng của người bệnh về việc cung cấp thông tin cần thiết trước mổ tái tạo dây chằng chéo trước ở thời điểm 2-3 giờ ngay trước giờ đi mổ.

Bộ câu hỏi phỏng vấn gồm 4 phần. Phần thứ nhất đánh giá lượng thông tin được cung cấp cho người bệnh trước mố nội soi tái tạo dây chằng chéo trước khớp gối trên 10 khía cạnh khác nhau. Mỗi một khía cạnh có những câu hỏi định tính và những câu hỏi định lượng dùng để đánh giá sự hiểu biết của người bệnh về lĩnh vực được lượng giá. Trên mỗi khía cạnh, nội dung câu trả lời của người bệnh được phân loại thành kém hiểu biết (đáp án sai), hiểu biết một phần (đáp án đúng nhưng không đầy đủ) và hiểu biết (đáp án đúng và đây đủ). Phần thứ nhất đánh giá mức độ cung cấp thông tin từ nhân viên y tế đến người bệnh. Thang đo thứ bậc Likert được sử dụng để đánh giá mức độ cung cấp thông tin, từ mức độ 1 (quá ít), mức độ 2 (ít), mức độ 3 (vừa phải), mức độ 4 (nhiều), mức độ 5 (quá nhiều). Phần thứ hai đánh giá mức độ dễ hiểu của các thông tin được cung cấp trước mổ được cung cấp bởi các nhân viên y tế cho người bệnh. Cũng tương tự đánh giá mức độ cung cấp thông tin từ nhân viên y tế đến người bệnh, thang điểm Likert 5 bậc được sử dụng để đánh giá gồm mức độ 1 (rất dễ hiểu), mức độ 2 (dễ hiểu), mức độ 3 (bình thường), mức độ 4 (hơi khó hiểu) và mức độ 5 (rất khó hiểu). Phần thứ 3 đánh giá mức độ hài lòng của người bệnh về việc cung cấp cung cấp thông tin cần thiết trước mổ nội soi tái tạo dây chằng chéo trước. Cũng tương tự như các phần trên, thang điểm Likert 5 bậc được sử dụng để dánh giá gồm mức độ 1 (rất không hài lòng), mức đô 2 (không hài lòng), mức độ 3 (bình thường), mức độ 4 (hài lòng), mức độ 5 (rất hài lòng) [3]. Cuối cùng, người bệnh được khuyến khích được đặt câu hỏi liên quan đến bất kỳ thông tin nào mà người bệnh cần làm rõ trước khi phẫu thuật và nghiên cứu viên sẽ trả lời một cách đầy đủ. Những vấn đề mà người bệnh thiếu kiến thức được nghiên cứu viên cung cấp đầy đủ cho người bệnh trước khi đi mổ.

2.4 Xử lý số liệu. Số liệu được nhập liệu và phân tích bằng phần mềm SPSS 25.0. Các biến số phân loại được trình bày dưới dạng tỷ lệ. Các biến số liên tục được trình bày dưới dạng trung bình \pm độ lệch chuẩn hặc trung vị (độ trải giữa 25\%- 75\%). Sử dung kiểm định KolmogorovSmirnov để đánh giá biến số có phân bố chuẩn.

2.5 Đạo đức nghiên cứu. Người bệnh được khám và chỉ định mổ bởi hội đồng chuyên môn của Bệnh viện Đại học Y Hà Nội. Đề cương 
nghiên cứu được phê duyệt bởi hội đồng đề tài khoa học của Trường Đại học Y Hà Nội. Các chuẩn mực đạo đức nghiển cứu y học được tôn trọng trong suốt quá trình thực hiện nghiên cứu.

\section{KẾT QUẢ NGHIÊN CỨU}

\section{1 Đặc điểm chung của đối tượng} nghiên cứu

Bảng 1: Đặc điểm chung của nhóm nghiên cứu ( $n=86)$

\begin{tabular}{|c|c|c|}
\hline \multirow{2}{*}{$\begin{array}{c}\text { Tuổi trung } \\
\text { bình (biên độ) }\end{array}$} & \multicolumn{2}{|c|}{$32,6 \pm 9,29(18-50)$ tuổi } \\
\hline \multirow{2}{*}{ Giới tính } & Nam & $72(83,7 \%)$ \\
\cline { 2 - 3 } & Nữ & $14(16,3 \%)$ \\
\hline \multirow{2}{*}{$\begin{array}{c}\text { Trình độ học } \\
\text { vấn }\end{array}$} & $>$ lớp 12 & $44(51,2 \%)$ \\
\cline { 2 - 3 } & $\leq$ lớp 12 & $42(48,8 \%)$ \\
\hline
\end{tabular}

Đa số người bênh của nhóm nghiên cứu là nam giới, chiếm 83,7\%, với độ tuổi trung bình 32,6 tuổi, trình độ học vấn trên lớp 12 chiếm $51,2 \%$ và trình độ học vấn dưới lớp 12 chiếm 48,8\%.

\subsection{Lượng thông tin được cung cấp đến người bênh}

\section{Bảng 2: Đánh giá lượng thông tin được cung cấp từ nhân viên y tế (n=86)}

\begin{tabular}{|c|c|c|c|c|c|c|c|c|}
\hline \multirow{2}{*}{ Tiêu chí đánh giá } & \multirow{2}{*}{$\begin{array}{l}\text { Số } \\
\text { NB }\end{array}$} & \multicolumn{5}{|c|}{ Thang đo Likert } & \multirow{2}{*}{$\begin{array}{c}\text { Trung } \\
\text { vị }\end{array}$} & \multirow{2}{*}{$\begin{array}{c}\text { Độ trải } \\
\text { giữ̛a* }\end{array}$} \\
\hline & & $\mathbf{1}$ & 2 & 3 & 4 & 5 & & \\
\hline Chẩn đoán bệnh & 86 & 0 & 12 & 54 & 20 & 0 & 3 & 3 \\
\hline Các tổn thương giải phẩu của khớp gối & 86 & 7 & 21 & 37 & 21 & 0 & 3 & $2-3$ \\
\hline Lý do phải mổ & 86 & 26 & 14 & 19 & 37 & 0 & 3 & $1-4$ \\
\hline Can thiệp của bác sĩ trong mố & 86 & 11 & 17 & 14 & 44 & 0 & 4 & $2-4$ \\
\hline Cảm giác của người bênh sau mố & 86 & 63 & 15 & 8 & 0 & 0 & 1 & 1 \\
\hline Đau và kiểm soát đau sau mổ & 86 & 46 & 16 & 19 & 9 & 0 & 1 & $1-3$ \\
\hline & 86 & 6 & 13 & 17 & 60 & 0 & 4 & $3-4$ \\
\hline Thời gian c & 86 & 49 & 10 & 13 & 12 & 2 & 1 & $1-3$ \\
\hline Khả năng thành công của ca mố & 86 & 22 & 14 & 12 & 25 & 13 & 3 & $1-4$ \\
\hline Lưu ý trong sinh hoạt sau mố & 86 & 16 & 29 & 27 & 14 & 0 & 2 & $2-3$ \\
\hline
\end{tabular}

Độ trải giữa* (biên độ 25\%- 75\%), Likert 1: rất ít thông tin, Likert 2: ít thông tin, Likert 3: vừa đủ thông tin, Likert 4: nhiêu thông tin, Likert 5: rất nhiều thông tin.

Các thông tin về chẩn đoán bênh, tổn thương giải phẫu của khớp gối, lý do phải mổ, can thiệp của bác sĩ trong mổ, các biến chứng chính sau mổ, khả năng thành công của ca mổ được cung cấp nhiều hơn so với các thông tin về cảm giác của người bệnh sau mổ, đau và kiểm soát đau sau mổ, thời gian cần nghỉ việc sau mổ và các lưu ý trong sinh hoạt sau mổ.

\subsection{Mức độ dễ hiểu của các thông tin được cung cấp}

Bảng 3: Đánh giá mức độ dễ hiếu của các thông tîn được cung cấp (n= 86)

\begin{tabular}{|c|c|c|c|c|c|c|c|c|}
\hline \multirow{2}{*}{ Tiêu chí đánh giá } & \multirow{2}{*}{$\begin{array}{l}\text { Số } \\
\text { NB }\end{array}$} & \multicolumn{5}{|c|}{ Thang đo Likert } & \multirow{2}{*}{$\begin{array}{c}\text { Trung } \\
\text { vị }\end{array}$} & \multirow{2}{*}{$\begin{array}{c}\text { Độ trải } \\
\text { giữa* }\end{array}$} \\
\hline & & 1 & 2 & 3 & 4 & 5 & & \\
\hline Chẩn đoán bệnh & 86 & 26 & 35 & 18 & 7 & 0 & 2 & $1-3$ \\
\hline Các tổn thương giải phầu của khớp gối & 86 & 15 & 23 & 47 & 1 & 0 & 3 & $2-3$ \\
\hline Lý do phải mổ & 86 & 11 & 34 & 35 & 6 & 0 & 2 & $2-3$ \\
\hline Can thiệp của bác sĩ trong mố & 86 & 6 & 14 & 45 & 19 & 2 & 3 & 3 \\
\hline Cảm giác của người bệnh sau mố & 86 & 4 & 14 & 57 & 11 & 0 & 3 & $2-3$ \\
\hline Đau và kiểm soát đau sau mố & 86 & 13 & 31 & 31 & 8 & 3 & 2 & $2-3$ \\
\hline Biến chứng sau mổ & 86 & 6 & 41 & 32 & 7 & 0 & 2 & $2-3$ \\
\hline Thời gian cần nghỉ việc sau mố & 86 & 15 & 37 & 29 & 5 & 0 & 2 & $2-3$ \\
\hline Khả năng thành công của ca mổ & 86 & 7 & 14 & 52 & 13 & 0 & 3 & 3 \\
\hline Lưu ý trong sinh hoạt sau mố & 86 & 8 & 23 & 38 & 17 & 0 & 3 & $2-3$ \\
\hline
\end{tabular}

Đô trải giữa* (biên độ 25\%- 75\%), Likert 1: rất dễ hiểu, Likert 2: dễ hiểu, Likert 3: bình thường, Likert 4: khó hiểu, Likert 5: rất khó hiểu.

Bên cạnh các thông tin được truyền đạt một cách dễ hiểu, những thông tin về tổn thương giải phẫu của khớp gối, can thiệp của bác sĩ trong mố, cảm giác của người bênh sau mố, khả năng thành công của ca mổ và các lưu ý trong sinh hoạt sau mổ được cung cấp chưa thực sự dễ hiểu.

3.4 Sự hài lòng của người bệnh về các thông tin được cung cấp trước mổ 
Bảng 4: Đánh giá sự hài lòng của người bệnh về các thông tin được cung cấp ( $n=86)$

\begin{tabular}{|c|c|c|c|c|c|c|c|c|}
\hline \multirow{2}{*}{ Tiêu chí đánh giá } & \multirow{2}{*}{$\begin{array}{l}\text { Số } \\
\text { NB }\end{array}$} & \multicolumn{5}{|c|}{ Thang đo Likert } & \multirow{2}{*}{$\begin{array}{c}\text { Trung } \\
\text { vi }\end{array}$} & \multirow{2}{*}{$\begin{array}{c}\text { Độ trải } \\
\text { giữa* }\end{array}$} \\
\hline & & $\mathbf{1}$ & 2 & 3 & 4 & 5 & & \\
\hline Chấn đoán bênh & 86 & 15 & 27 & 39 & 5 & 0 & 3 & $2-3$ \\
\hline Các tốn thương giải phâu của khớp gối & 86 & 9 & 29 & 35 & 13 & 0 & 3 & $2-3$ \\
\hline Lý do phải mố & 86 & 11 & 25 & 37 & 10 & 3 & 3 & $2-3$ \\
\hline Can thiệp của bác sĩ trong mố & 86 & 3 & 36 & 35 & 12 & 0 & 3 & $2-3$ \\
\hline Cảm giác của người bệnh sau mố & 86 & 24 & 37 & 25 & 0 & 0 & 2 & $1-3$ \\
\hline Đau và kiểm soát đau sau mố & 86 & 14 & 35 & 34 & 3 & 0 & 2 & $2-3$ \\
\hline Biến chứng sau mố & 86 & 8 & 30 & 28 & 17 & 3 & 3 & $2-4$ \\
\hline Thời gian cần nghỉ việc sau mố & 86 & 5 & 33 & 27 & 19 & 2 & 3 & $2-3$ \\
\hline Khả năng thành công của ca mố & 86 & 7 & 24 & 23 & 19 & 12 & 3 & $2-4$ \\
\hline Lưu ý trong sinh hoạt sau mố & 86 & 16 & 28 & 41 & 1 & 0 & 2 & $2-3$ \\
\hline
\end{tabular}

Độ trải giữa* (biên độ 25\%- 75\%), Likert 1: rất không hài lòng, Likert 2: không hài lòng, Likert 3: bình thường, Likert 4: hài lòng, Likert 5: rất hài lòng.

Đa số người bệnh chưa thực sự hài lòng với quá trình cung cấp thông tin cần thiết trước mổ.

3.5 Thông tin người bệnh mong muốn được biết trước mổ

Bảng 5: Đánh giá nhu cầu được biêt thông tin trước mố $(n=86)$

\begin{tabular}{|c|c|c|c|}
\hline Tiêu chí đánh giá & Có & Không & $\begin{array}{l}\text { Không } \\
\text { trả lời }\end{array}$ \\
\hline Chấn đoán bệnh & 86 & 0 & 0 \\
\hline $\begin{array}{l}\text { Các tốn thương giải } \\
\text { phẫu của khớp gối }\end{array}$ & 80 & 6 & 0 \\
\hline Lý do phải mố & 82 & 4 & 0 \\
\hline $\begin{array}{c}\text { Can thiệp của bác sĩ } \\
\text { trong mổ }\end{array}$ & 80 & 6 & 0 \\
\hline $\begin{array}{c}\text { Cảm giác của người } \\
\text { bệnh sau mổ }\end{array}$ & 64 & 22 & 0 \\
\hline $\begin{array}{c}\text { Đau và kiếm soát } \\
\text { đau sau mổ }\end{array}$ & 57 & 29 & 0 \\
\hline $\begin{array}{l}\text { Các biến chứng có thể } \\
\text { sảy ra sau mổ }\end{array}$ & 64 & 22 & 0 \\
\hline $\begin{array}{c}\text { Thời gian cần nghỉ } \\
\text { việc sau mổ }\end{array}$ & 55 & 31 & 0 \\
\hline $\begin{array}{c}\text { Khả năng thành công } \\
\text { của ca mố }\end{array}$ & 86 & 0 & 0 \\
\hline $\begin{array}{c}\text { Lưu ý trong sinh hoạt } \\
\text { sau mổ }\end{array}$ & 85 & 1 & 0 \\
\hline Chi phí điều trị & 71 & 15 & 0 \\
\hline
\end{tabular}

Đa số người bênh có nhu cầu được biết các thông tin về bệnh, về phẫu thuật và chăm sóc sau mổ. Bên cạnh đó đa số người bệnh còn có nhu cầu thông tin về chi phí điều trị.

\section{BÀN LUÂ̂N}

Chia sẻ quyết định điều trị dựa trên hiểu biết của người bệnh về những thông tin được cung cấp trước mổ là điều lý tưởng trong thực hành y khoa nói chung và phẫu thuật chấn thương chỉnh hình nói riêng. Lý tưởng nhất, quyết định đồng ý thủ thuật, phẫu thuật của người bệnh là sự thừa nhân chính thức rằng ho đã nhân được các thông tin về bệnh tật, về thủ thuật và phẫu thuật một cách đầy đủ và dễ hiểu, cho phép họ đưa ra các quyết định sáng suốt để tiếp tục nhận các can thiêp y tế. Điều này tao dựng nển mối quan hệ thầy thuốc- người bệnh không chỉ ngay trong thời gian phẫu thuật mà còn trong cả quá trình theo dõi, điều trị trước mổ và sau mổ. Đây cũng chính là vấn đề cốt lõi của việc lấy người bênh làm trung tâm trong công tác khám chữa bệnh. Ba tiêu chí cơ bản để có được sự chia sẻ quyết định điều trị dựa trên hiểu biểt của người bệnh là người bênh phải có thẩm quyền, được cung cấp thông tin đầy đủ và không bị ép buộc. Bác sĩ phải cung cấp đầy đủ thông tin cho người bệnh. Người bệnh phải có đủ năng lực để hiểu và đánh giá thông tin được cung cấp, truyền đạt các lựa chọn của họ, và hiểu được hậu quả của lựa chọn đó. Quyết định của người bệnh phải là tự nguyện [2]. Xét một cách toàn diện thì người bệnh trong nhóm nghiên cứu thỏa mãn tất cả các điêu kiên trên.

Rất khó để đánh giá một cách chuẩn mực rằng các thông tin được cung cấp ở mức độ nào, về các khía canh nào là đầy đủ đối với với người bênh để người bênh có thể chia sẻ quyết định điều trị với người thầy thuốc. Đặc biệt trong văn hóa của người Việt Nam, khi đển bệnh viện đều có xu hướng "trăm sự nhờ bác sĩ". Một số nhân viên y tế có xu hướng cung cấp nhiêu thông tin trong khi đó một số lại có xu hướng cung cấp khối lượng thông tin ít ỏi cho người bệnh. Trong nghiên cứu này chúng tôi đánh giá lượng thông tin được cung cấp trên 10 vấn đề cơ bản xoay quanh việc chẩn đoán, điều trị trong và sau mổ. Theo Hội y khoa Hoa Kỳ, các thông tin tối thiểu cần được cung cấp cho người bệnh bao gồm: chẩn đoán, bản chất của các can thiệp y khoa, gánh nặng cho người bệnh, nguy cơ có thể gặp, 
lơi ích mong muốn từ các can thiêp, các lựa chon thay thế bao gồm cả việc từ chối điều trị [4]. Theo kết quả của nghiên cứu, các thông tin liên quan đến bệnh và phẫu thuật được cung cấp môt cách đầy đủ tuy nhiên những thông tin về chăm sóc sau mổ chưa được quan tâm đúng mực trong quá trinh cung cấp thông tin trước mổ.

Tai Khoa chấn thương chỉnh hình và $Y$ hoc thể thao của Bệnh viện Đại học Y Hà Nội, việc cung cấp thông tin cần thiết trước phẫu thuật nội soi tái tạo dây chằng chéo trước khớp gối được thực hiện bởi bác sĩ khám bênh (đồng thời là bác sĩ phẫu thuật) và bác sĩ nội trú chuyên ngành ngoại khoa đi luân khoa tại các cơ sở y tế. Việc cung cấp các thông tin cần thiết trước phẩu thuật dường như ít hơn so với những gì người bệnh mong đợi. Bác sĩ khám bênh có xu hướng giải thích ngắn gọn, nhanh và thậm chí có thể sử dụng những thuật ngữ chuyên ngành như một thói quen trong khi các bác sĩ nội trú lại thiếu kiến thức và kinh nghiêm về các vấn đề liên quan đến phẫu thuật nội soi tái tạo dây chằng chéo trước. Có vẻ như có sự mặc định cho rằng bác sĩ nội trú có khả năng trao đổi toàn bộ các thông tin liên quan đến phẫu thuật của người bệnh. Tuy nhiên thực tế không hẳn như vậy. Để trao đổi các thông tin cần thiết trước mổ một cách có hiệu quả cho người bệnh cần có kiển thức lý thuyết, kinh nghiệm thực tế. Chính vì thế có thể giải thích tại sao bên cạnh các thông tin được truyền đat một cách dễ hiểu còn có những thông tin về tổn thương giải phẫu của khớp gối, can thiêp của bác sĩ trong mổ, cảm giác của người bệnh sau mổ, khả năng thành công của ca mổ và các lưu ý trong sinh hoạt sau mổ được cung cấp chưa thực sự dễ hiểu.

Cung cấp thông tin cần thiết cho người bênh là một quá trình giao tiếp giữa thầy thuốc và người bệnh mà khi đó, thầy thuốc dùng những ngôn từ dễ hiểu, hình ảnh trực quan để giao tiếp với người bênh nhằm truyền đạt thông tin một cách hiệu quả nhất [2]. Thực tế cho thấy quá trình giao tiếp này có những rào cản nhất định. Trình độ học vấn, văn hóa, tuổi, nhận thức, khả năng ngôn ngữ... của người bênh được cho là những yếu tố ảnh hưởng đến quá trình giao tiếp. Mặt khác, các nghiên cứu kinh điển cho thấy mặc dù quá trình truyền đạt thông tin là đầy đủ, việc người bệnh nhớ lại những thông tin được cung cấp trong quá trình trao đổi giữa thầy thuốc với người bệnh là rất thấp. Sử dụng các hình ảnh trực quan, các mô hình, video dựng sẵn, hay nền tảng web trong quá trình giao tiếp giữa người bệnh và thây thuốc và các chương trình phổ biến kiến thức của điều dưỡng đều được chứng minh làm cải thiện hiệu quả của quá trình giao tiếp và khả năng nhớ lại của người bệnh [6],[7],[8].

Hài lòng người bệnh là một thước đo có hiệu quả trong thực hành y khoa lấy người bệnh làm trung tâm. Hài lòng đồng thời cũng là chia khóa để giảm thiểu những hiểu lầm, tranh cãi và thậm chí kiện tụng liên quan đến quá trình điều trị cho người bệnh. Sự hài lòng liên quan đến việc đáp ứng những mong muốn và nhu cầu của người bệnh. Điều này liên quan đến tất cả các khía cạnh trong tương tác giữa người bệnh và thầy thuốc. Nghiên cứu đã chỉ ra rằng, người bệnh chưa thật sự hài lòng với quá trình cung cấp những thông tin cần thiết trước mổ. Có nhiều lý do có thể giải thích cho luận điểm này: thông tin được thầy thuốc cung cấp không đây đủ so với nhu cầu của người bệnh, mỗi người bệnh lại có nhu cầu về các thông tin ưu tiên khác nhaù, sử dụng thuật ngữ chuyên ngành gây khó hiểu cho người bệnh, quá trình giao tiếp thiếu hiệu quả do người thiếu kỹ năng giao tiếp, sự không thống nhất về thông tin giữa các nhân viên y tế khác nhau.... Chính vì vậy, việc sử dụng những tài liệu đã được chuẩn bị bài bản cung cấp cho người bệnh sẽ không chỉ làm tăng hiệu quả của quá trình cung cấp thông tin trước mổ và còn tăng sự hài lòng của người bệnh với quá trình đó [1].

Đánh giá nhu cầu về thông tin của người bệnh đối với quá trình cung cấp thông tin cần thiết trước mổ tái tạo dây chằng chéo trước chúng tôi nhận thấy đa số người bệnh có nhu cầu được biết các thông tin về bệnh, về phẫu thuật và chăm sóc sau mổ. Ngoài ra người bệnh còn muốn biết về chi phí điều trị. Đánh giá nhu cầu thông tin của người bệnh giúp thầy thuốc xây dựng được nội dung cần thiết cho việc cung cấp thông tin trước mổ.

Điểm mạnh của nghiên cứu này là nhóm đối tượng nghiển cứu nằm trong 1 giới hạn tuổi hẹp, cùng mắc chung một tổn thương và cùng trải qua một phẫu thuật phổ biến là nội soi tái tạo dây chằng chéo trước khớp gối nển quá trình cung cấp thông tin của thây thuốc đối với người bệnh tương đối đồng nhất. Hạn chế lớn nhất trong nghiên cứu của chúng tôi là kiểm soát sai số của các câu trả lời vì các câu trả lời đều dựa trên sự nhớ lại của người bênh. Bảng câu hỏi của chúng tôi dựa trên một số nghiên cứu của các tác giả nước ngoài mà chưa được tiến hành khảo sát và xác thực ở Việt Nam trước khi tiến hành nghiên cứu. Bên cạnh đó những tài liệu chúng tôi tham khảo cũng không khẳng định rằng bộ 
câu hỏi được sử dụng để đánh giá hiểu biết và sự hài lòng của người bệnh có được thiết kế riêng để đánh giá cho người bệnh mổ tái tạo dây chằng chéo trước khớp gối hay cho người bệnh mổ nội soi gối nói chung và kể cả cho nhứng người bệnh có đứt dây chằng chéo trước khớp gối nhưng không mổ. Tuy vậy những kết quả bước đâuu thu thập được cũng có những ý nghĩa nhất định, giúp cho chúng ta có một cái nhìn bước đầu về tình trạng ký cam kết phẫu thuật không đồng nghĩa với việc người bệnh thực sự hiểu và chia sẻ quyết định điều trị với thầy thuốc. Kết quả nghiên cứu này sẽ là cơ sở để thực hiện các đánh giá tổng kết sâu rộng hơn sau này về vấn đề này.

\section{KẾT LUÂNN}

Người bệnh mổ tái tạo dây chằng chéo trước khớp gối được cung cấp đủ thông tin liên quan đến bệnh và phẫu thuật nhưng còn thiếu các thông tin về quá trình chăm sóc và điều trị sau mổ. Một số thông tin cần thiết được truyền tải chưa thực sự dễ hiểu. Đa số người bệnh chưa cảm thấy hài long với quá trình cung cấp thông tin cần thiết trước mổ cho phẫu thuật tái tạo dây chằng chéo trước khớp gối.

\section{TÀI LIÊU THAM KHẢO}

1. Hallock J.L., Rios R., and Handa V.L. (2017). Patient satisfaction and informed consent for surgery. Am J Obstet Gynecol, 217(2), 181.e1-181.e7.

2. Cocanour C.S. (2017). Informed consent-It's more than a signature on a piece of paper. Am J Surg, 214(6), 993-997.

3. McGaughey I. (2004). Informed consent and knee arthroscopies: an evaluation of patient understanding and satisfaction. The Knee, 11(3), 237-242.

4. Chapter 2: opinions on consent, communication \& decision making. In: American Medical Association Code of Medical Ethics; 2016:1e2. https://www. ama-assn.org/delivering-care/ama-code-medicalethics. Accessed April 13, 2017.

5. Hutson M.M. and Blaha J.D. (1991). Patients' recall of preoperative instruction for informed consent for an operation. J Bone Joint Surg Am, 73(2), 160-162.

6. Rossi M.J., Guttmann D., MacLennan M.J., et al. (2005). Video Informed Consent Improves Knee Arthroscopy Patient Comprehension. Arthrosc J Arthrosc Relat Surg, 21(6), 739-743.

7. Yin B., Goldsmith L., and Gambardella $R$. (2015). Web-Based Education Prior to Knee Arthroscopy Enhances Informed Consent and Patient Knowledge Recall: A Prospective, Randomized Controlled Study. J Bone Jt Surg, 97(12), 964-971.

8. Cornoiu A., Beischer A.D., Donnan L., et al. (2011). Multimedia patient education to assist the informed consent process for knee arthroscopy: Multimedia patient education for surgery. ANZ J Surg, 81(3), 176-180.

\section{XÂY DỰNG THANG ĐO MỨC Độ CHẤP NHẬN TIÊM CHỦNG VẮC-XIN PHÒNG NGỪA COVID-19 TRÊN ĐỐI TƯợNG SINH VIÊN}

\section{TÓM TẮT}

Vắc-xin là giải pháp quan trọng nhất để ngăn chặn đại dịch COVID-19 lây lan nhanh chóng. Hiện nay trền thế giới nhiều nghiên cứu đánh giá mức đô chấp nhân tiêm chủng vắc-xin phòng ngửa COVID-19 trên đối tượng sinh viên tuy nhiên chưa có nghiên cứu nào tương tự được thực hiện trong bối cảnh tại Việt Nam. Đề tài được thực hiên nhằm muc đích xây dựng thang đo khảo sát mức độ chấp nhận tiêm chủng vắc-xin ngửa COVID-19 của sinh viên. Đ̇ề tài sử dung phương pháp nghiên cứu định tính (tổng quan lý thuyết nhằm xây dựng thang đo ban đâu và thảo luận nhóm tập trung để xây dựng thang đo sơ bộ) và định lượng (bao gồm kiểm định Cronbach alpha và phân tích EFA) để hiệu chỉnh thang đo sơ bộ, từ đó đánh giá được độ tin cậy và giá trị của thang đo và hoàn thiện thang đo

*Đai hoc Y Dước Thành phố Hồ Chí Minh

Chịu trách nhiệm chính: Nguyễn Thị Thu Thủy

Email: nguyenthuthuy@ump.edu.vn

Ngày nhận bài: 7.6.2021

Ngày phản biên khoa học: 2.8.2021

Ngày duyệt bài: 9.8.2021 chính thức. Đề tài đã xây dưng thang đo mức đô chấp nhận tiêm chủng vắc-xin trển đối tượng sinh viển bao gồm 5 nhân tố tiền đề tâm lý tiêm chủng (sự tin tưởng, sự cân nhắc, trách nhiệm cộng đồng, sự tự mãn và hạn chế) với 15 biến quan sát. Thang đo đạt độ tin cậy với hệ số Cronbach's alpha của các nhân tố đều lớn hơn 0,7 và tương quan biến tổng các biến quan sát đều lớn hơn 0,3 . Phân tích EFA cho kết quả đạt yêu câu một thang đo tốt.

Tư khóa: mức độ chấp nhận vắc-xin, do dự tiêm chủng, COVID-19.

\section{SUMMARY \\ DEVELOPING SCALE OF COVID-19} VACCINE ACCEPTANCE AMONG STUDENTS

Vaccine is the most important solution to prevent the rapidly spreading COVID-19 pandemic. Currently, many studies have assessed the acceptability of vaccination against COVID-19 among students in the world but none has been conducted in the context of Vietnam. This study aimed to build a scale to assess the acceptance of COVID-19 vaccination among students. The research used qualitative methods (theoretical overview to build the initial scale and 